Population Study of Western Grebes in Alberta 2001-2009: Implications for Management and Status Designation

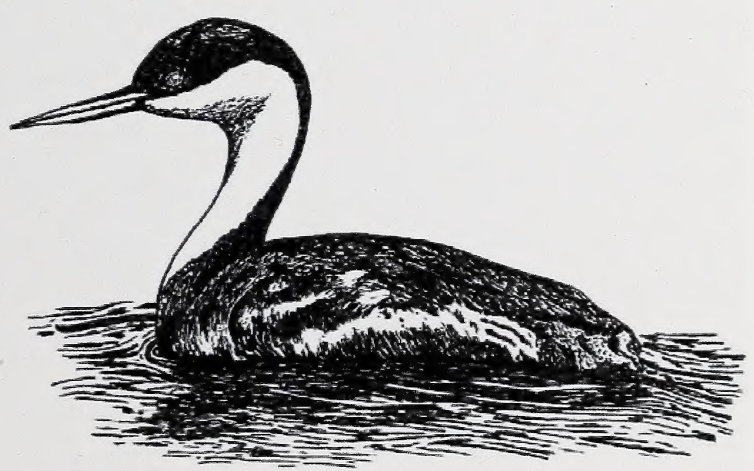

Alberta Species at Risk Report No. 138 
Digitized by the Internet Archive in 2016

https://archive.org/details/populationstudyo00woll_0 


\title{
Population Study of Western Grebes in Alberta 2001- 2009: Implications for Management and Status Designation
}

\author{
Hugh Wollis and Curtis Stratmoen
}

Alberta Species at Risk Report No. 138

November 2010

\section{Government of Alberta}


Publication No.: I/479

ISBN: 978-0-7785-9946-3 (Printed Edition)

ISBN: 978-0-7785-9237-2 (On-line Edition)

ISSN: 1496-7219 (Printed Edition)

ISSN: 1496-7146 (On-line Edition)

Cover Illustration: Stephen Hanus

For copies of this report, contact:

Information Centre - Publications

Alberta Environment / Alberta Sustainable Resource Development

Main Floor, Great West Life Building

9920108 Street

Edmonton, Alberta, Canada T5K 2M4

Telephone (780) 422-2079

\section{OR}

Visit our website at:

http://srd.alberta.ca/BioDiversityStewardship/SpeciesAtRisk/ProgramReports.aspx

This publication may be cited as:

Wollis, H., and C. Stratmoen. 2010. Population Study of Western Grebes in Alberta 2001-2009: Implications for Management and Status Designation. Alberta Sustainable Resource Development, Fish and Wildlife Division, Alberta Species at Risk Report No. 138. Edmonton, AB. 18 pp. 


\section{EXECUTIVE SUMMARY}

This project was initiated in 2001 to monitor population trends and distribution of western grebes (Aechmophorus occidentalis) in Alberta. The project began in the Stony Plain study area, and then expanded to other areas of the province where the species occurs. Surveys of known colonies and a search for other breeding sites have continued each year through 2009. Biologists searched for western grebe colonies from the northern extreme of the breeding range in northeast and northwest Alberta, through the parkland and prairies, south to the United States border. Data from previous field seasons (20012006) have been published in earlier reports in this series.

The goal in 2007-09, the final formal seasons of study, was to locate any previously unknown colonies in Alberta and to monitor significant western grebe colonies identified in previous surveys. These data will assist Alberta's Endangered Species Conservation Committee (ESCC) in making an informed recommendation as to the status of the western grebe in Alberta and its management.

In 2008, to ensure that no large colonies (a "large" colony is defined as having at least 50 nests or 100 adults) of western grebes had been missed during the provincial surveys, several sources were consulted. These included: the most recent database of the Bird Atlas Project of the Federation of Alberta Naturalists, the Royal Alberta Museum, the Canadian Wildlife Service, several prominent naturalists, Biologists with Alberta Tourism, Parks and Recreation (Alberta Conservation Information Management System, ACIMS, formerly ANHIC), Wildlife Biologists with Fish and Wildlife Division (FWD), as well as file reports and data from FWD. Known colony sites were revisited each field season and new potential breeding lakes were also investigated.

There are three critical points that can be drawn from these studies. First, Alberta has at least 10,000 western grebes, which represents about $10 \%$ of the global (that is, North American) population. Most of these birds are concentrated in only nine nesting colonies as of 2009. Second, most of those colonies are located in areas where development was once minimal, but is now increasing. Since the commencement of the study, four of the larger colonies have faced challenges as a result of conflicting land uses. Finally, many colonies across the province have disappeared or undergone dramatic declines in recent years. While definitive studies on inter-lake movement of grebes are lacking, grebes from these colonies do not appear to have established new colonies elsewhere.

Lack of historical data on lakes where western grebes have occurred, or may have occurred and are no longer present, precludes definitive statements about causes of abandonment. However, it is recommended that steps be taken now to address factors that can lead to colony abandonment. Although it is possible that Alberta's western grebes may be moving to other jurisdictions, it is considered unlikely; similar declines are occurring elsewhere in their range. Protection of western grebe breeding habitat is critical to the maintenance and recovery of the species in the province. The Fish and Wildlife Division (FWD) is currently initiating this by pursuing application of Protective Notations (PNTs) and seasonal sanctuaries to western grebe colonies. 


\section{ACKNOWLEDGEMENTS}

This project was expanded since its inception in 2001 to become provincial in scope. We have relied on many of our Fish and Wildlife Division colleagues in other areas throughout the province to assist in data collection. Prominent among these include, S. Hanus, G. Berg. L. Wilkinson, C. Found, A. Hubbs, M. Heckbert, D. Moyles, D. Prescott, K. Norstrum, A. Fontaine and C. Kemper. Many other staff assisted in various ways as did several volunteers; the numbers are so large as to preclude mentioning them all here. Their assistance has been greatly appreciated and we thank them for their efforts. Additionally, we are grateful to G. Beyersbergen and W. Nordstrom who provided additional data for our project. In 2008-09, we worked closely with M. Erickson, a graduate student at the University of Alberta. Funding for the portion of the project from 2007-09 has been from the Fish and Wildlife Division of Alberta Sustainable Resource Development. This report was edited and reviewed by R. Gutsell and G. Berg. 


\section{TABLE OF CONTENTS}

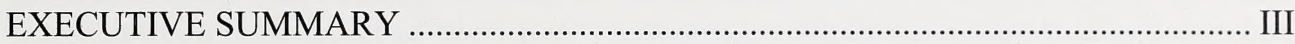

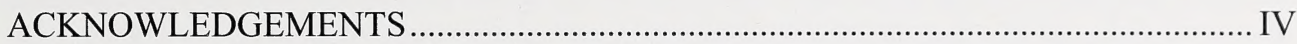

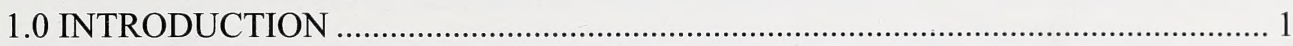

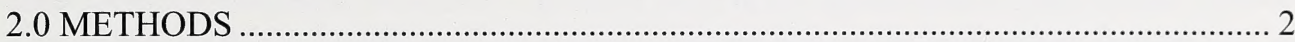

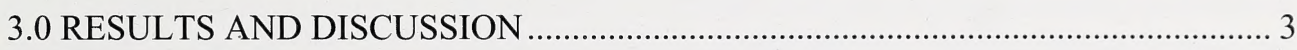

3.1 Habitat Requirements of Western Grebes in Alberta ................................................ 6

3.2 Threats to Western Grebe Populations ………………............................................ 7

3.3 Population Trends of Western Grebes in Alberta .................................................... 9

3.4 Alberta's Western Grebes in a North American Context ....................................... 12

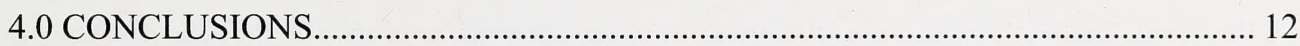

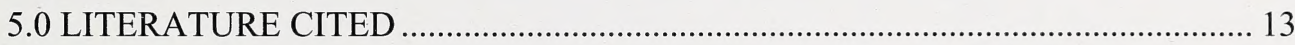

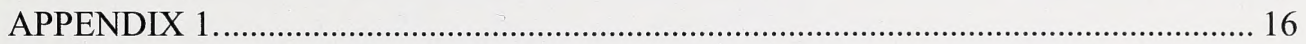

\section{LIST OF FIGURES AND TABLES}

Figure 1. North American Distribution of Western Grebes ..........................

Figure 2. Historical colonies of western grebes having at one time at least 50 nests or 100 breeding pairs...........................................................

Figure 3. Estimated total number of adult western grebes (nests x 2) in the Stony Plain

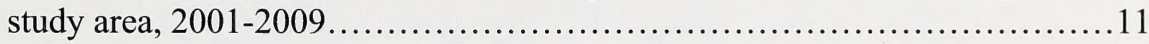

Table 1. Currently (2009) occupied lakes with more than 50 nests or 100 adults.................................................................... 5 


\subsection{INTRODUCTION}

The western grebe is North America's largest and most gregarious grebe, nesting in colonies numbering from a few to into the thousands (Storer and Nuechterlein 1992). The species is easily identified by a long, curved neck, contrasting black and white coloration, red eyes and thin, sharp bill (Fisher and Acorn 1998). They breed across the central and western portion of North America (Figure 1), and migrate nocturnally to the Pacific Coast to winter from Alaska and British Columbia, south to central Mexico (Burger 1997). Fall migration occurs from late August through mid-October, and spring migration inland occurs from late April through May (Semenchuk 1992). Western grebes feed primarily on fish, which may constitute up to 100\% of their diet (Blood and Backhouse 1999), so it is not surprising that they select fish-bearing lakes with deep water and large open areas for nesting (Storer and Nuechterlein, 1992). Grebes, unlike other colonial fish-eating birds, such as cormorants, stay on breeding lakes from May until fall migration. Western grebes construct nests of floating masses of vegetation anchored to and within stands of emergent aquatic vegetation.

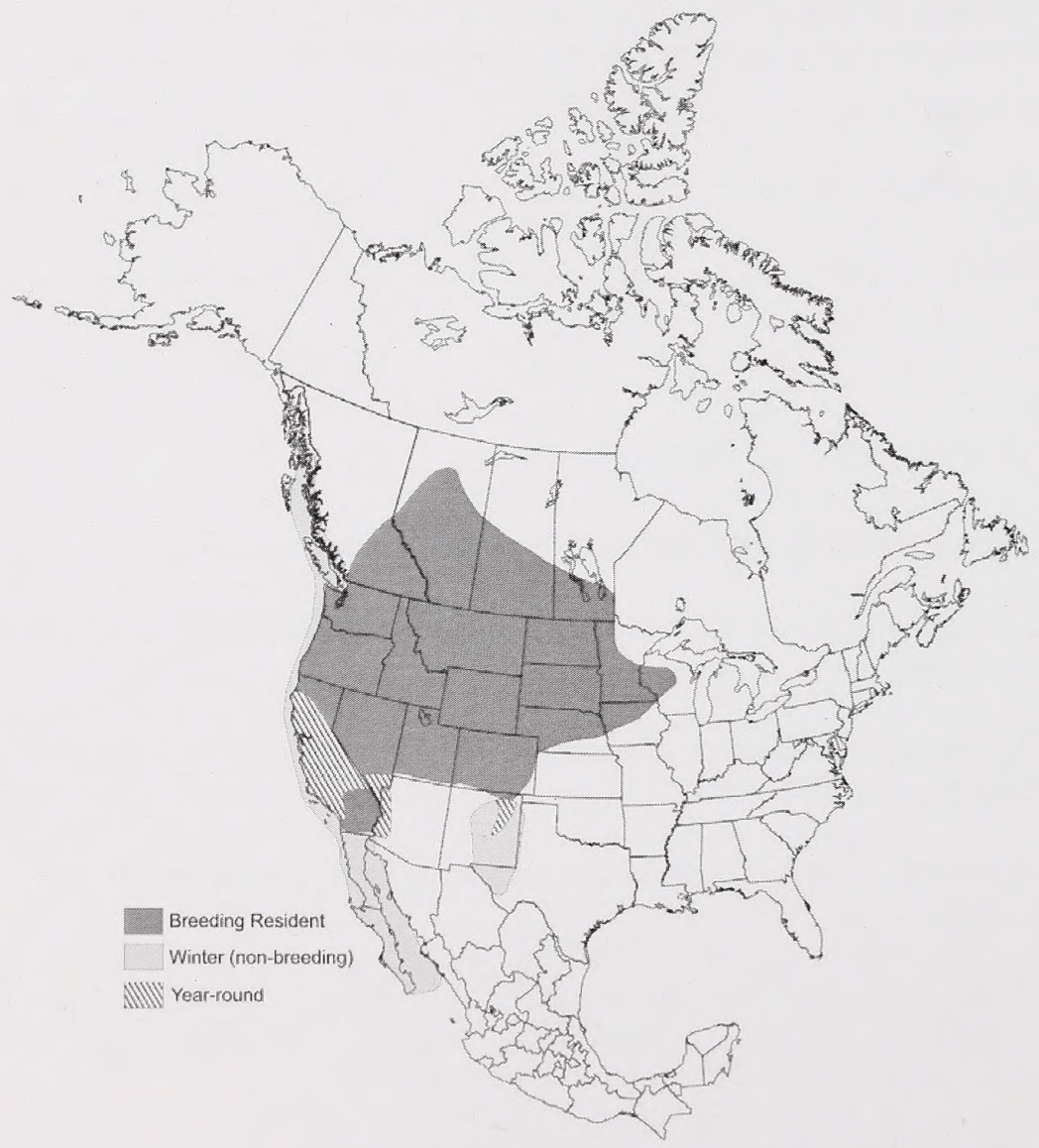

Figure 1. North American distribution of western grebes (from Alberta Sustainable Resource Development and Alberta Conservation Association 2006) 
Alberta's Fish and Wildlife Division began an assessment of western grebe populations in 2001 in response to the relatively sparse data available to quantify the General Status ranking. In 2005, western grebes in Alberta were ranked as "Sensitive" defined as "any species that is not at risk of extinction or extirpation but may require special attention or protection to prevent it from becoming at risk" (ASRD 2007). The study began with an examination of historical records. Field work began in the Stony Plain area then expanded to include the provincial range of the western grebe in Alberta. Survey protocols were developed and refined; population trends and distribution within the study area have been monitored; and specific threats to populations have been identified. Data gathered from 2001 to 2006 has been reported (Hanus 2002, Hanus 2002a, Hanus et al. 2002, Hanus et al. 2002a, Hanus et al. 2003, Berg et al. 2004, Found 2004, Found 2008, Kemper et al. 2008). In 2006, Alberta's Endangered Species Conservation Committee (ESCC) assessed the status of the western grebe based on these data, and recommended a status of Species of Special Concern. Their assessment led to an Initial Conservation Action Statement which stated in part:

"The Western Grebe should be identified as a 'Species of Special Concern' in Alberta. Amendments to the Wildlife Act should be enacted to facilitate this designation. Pending these legislative changes, this species should be identified as 'Special Concern' by Ministerial policy. Because of concerns about its habitat, the species' status should be considered for re-evaluation as soon as 2008 survey data are available."

With this direction, the study continued through into 2007 and, while it formally wrapped up in 2008, this report contains some additional follow-up data from 2009.

\subsection{METHODS}

At the outset of the study in 2001, many sources for information on known and historical nesting colonies and population estimates of western grebe colonies in Alberta were consulted (Hanus et al. 2002). Western grebes have been reported from 120 lakes in Alberta, either historically or currently.

To ensure that no colonies of western grebes that may have been discovered since the first review in 2001 were missed, in 2008 data from the following individuals and organizations were reviewed:

1. Fish and Wildlife Information Management System. This database is used by FWD to record observations of wildlife throughout the province. It was reviewed in both 2001 and 2008.

2. Federation of Alberta Naturalists' (FAN) Bird Atlas Database. In 2001, FAN provided their Breeding Bird database for western grebe data. In 2008, they provided their updated survey data that were gathered from 2002-2005.

3. Individuals from the Ornithology section of the Royal Alberta Museum provided information from their publications on western grebe observations.

4. The Canadian Wildlife Service provided data on western grebe observations from field work in Alberta from 2006-07 and on southern Alberta lakes in 2008. 
5. The Lesser Slave Lake Bird Observatory was contacted to see whether they had information unknown to us.

6. Alberta Tourism, Parks and Recreation was contacted for any occurrence records that could be found on their species tracking system (Alberta Conservation Information Management System, ACIMS, formerly ANHIC).

7. Wildlife Biologists working for FWD in Alberta were requested to search their files for any data on western grebes.

Where this new information suggested the presence of a colony at a particular lake, the lake was surveyed for evidence of nesting colonies. As per the usual protocol, previously identified colonies of western grebes were surveyed in June. If their presence was confirmed, a follow up nest count was performed immediately after the nesting season. Appropriate methodology for western grebe surveys in Alberta was the subject of early work in this study and has been reported in detail elsewhere (Hanus et al. 2002c, and Found and Hubbs 2004).

The focus of surveys in 2008 and 2009 was to revisit lakes with western grebe colonies that had been identified in previous surveys, and to locate any previously unknown colonies in northwest, central and southern Alberta. M. Erickson, a graduate student at the University of Alberta, partnered with us on the project in 2007 to 2009 and monitored additional lakes.

\subsection{RESULTS AND DISCUSSION}

While western grebes are widely distributed throughout the province, breeding is limited to fish-bearing lakes with suitable reed beds for nesting habitat, and then only to portions of those lakes where disturbance or habitat change has not occurred. There may also be additional unknown factors that grebes respond to. While the data search of 2001 found 600 lakes within the range distribution for western grebes in Alberta, grebes had been reported at only 141 of these lakes. The most important areas for western grebes in Alberta are the large nesting colonies. This is where the 2007-09 study focused its efforts, for it is these colonies that are potentially at risk, and loss of these colonies would have the greatest effect on the Alberta population. Of the 141 lakes where grebes have been reported to FWD, seven lakes, all in the Boreal Region (Strong and Leggat 1981), had at one time over 1000 adult grebes. Four other lakes - three in the Boreal Region, and a single one in the Parkland Region had between 500 and 1000 adults. A 'large colony' is defined as having at least 50 nests or 100 adults. The historical data gathered in 2001 and rechecked in 2008, plus the field data from this study, showed that there have been fewer than 30 lakes with 100 or more breeding adults (Appendix 1). In 2009, it was confirmed that there were only nine colonies with 100 or more breeding adults (Figure 2, Table 1). Two additional lakes may still have more than 100 breeding adults: Hastings Lake, where the low water level threatens the nesting habitat, and Gull Lake, where the first record of breeding success was reported with over 100 adults. These two colonies require further monitoring to determine whether they are stable.

During the nine years of the study, only 2 lakes were discovered with greater than 50 nests that had not been identified previously in the historic literature. Therefore there is a 
high level of confidence that a major colony in Alberta has not been missed during this study period.

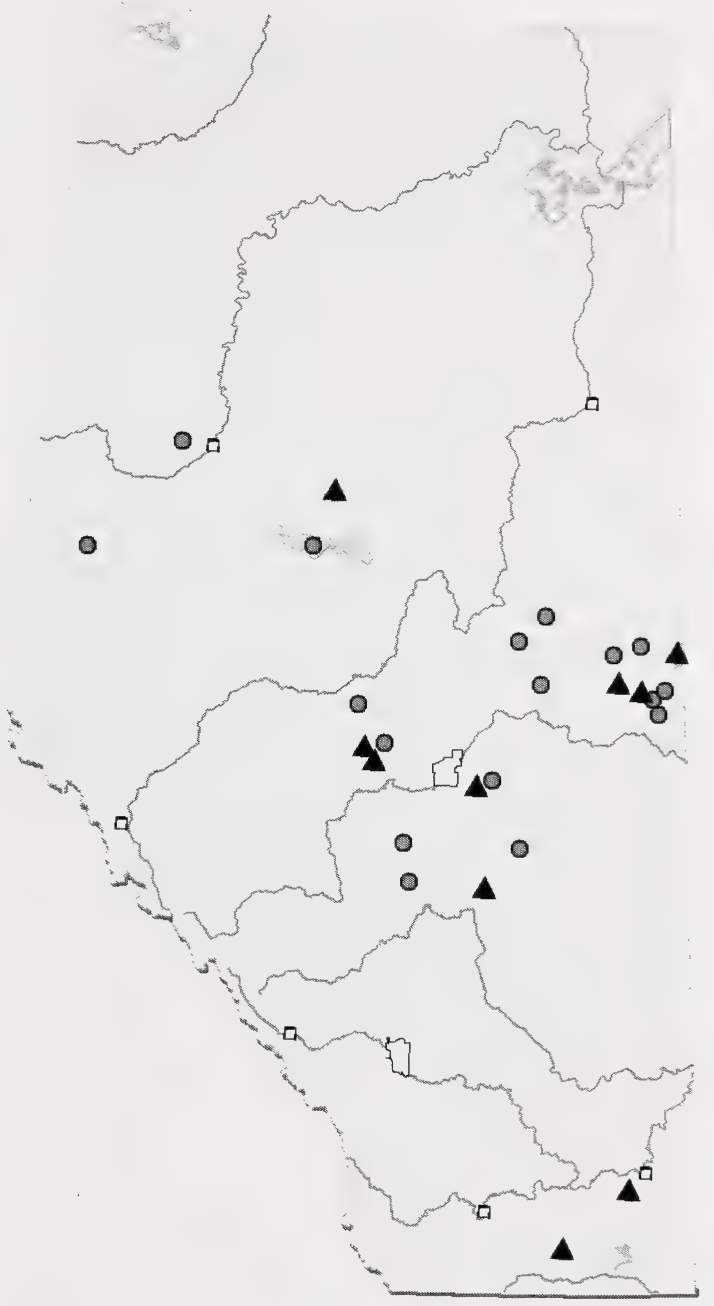

Figure 2. Historical colonies of western grebes having at one time at least 50 nests or 100 adults. $\mathbf{O}=$ historically occupied lakes with $100+$ grebes, $\boldsymbol{\Delta}=$ currently (2009)* occupied lakes with $100+$ grebes (*includes Hastings Lake that has an uncertain status with 14 nests found but 100+ birds witnessed using the lake). 
Table 1. Currently (2009) occupied lakes with more than 50 nests or 100 adults.

\begin{tabular}{|l|l|l|l|l|l|}
\hline LAKE & $\begin{array}{l}\text { LOCATION } \\
\text { (Region) }\end{array}$ & $\begin{array}{l}\text { \#Adults } \\
\text { Most } \\
\text { Recent } \\
\text { Estimate }\end{array}$ & YEAR & $\begin{array}{l}\text { \# Adults } \\
\text { Highest } \\
\text { Estimate }\end{array}$ & YEAR \\
\hline Utikuma & NW Boreal & 1220 & 2009 & 2200 & 2000 \\
\hline Lac La Biche & NE Boreal & 3226 & 2007 & 3226 & 2007 \\
\hline Cold & NE Boreal & 582 & 2008 & 2000 & 1979 \\
\hline Moose & NE Boreal & 353 & 2008 & 400 & 1990 \\
\hline Lake Isle & Boreal (Central) & 130 & 2009 & 154 & 2007 \\
\hline Wabamun & Boreal (Central) & 340 & 2009 & 1510 & 2002 \\
\hline Buffalo & Parkland & 888 & 2008 & 1030 & 2006 \\
\hline Crow Indian & Prairie & 100 & 2009 & 100 & 2009 \\
\hline Murray & Prairie & 107 & 2009 & 107 & 2009 \\
\hline
\end{tabular}

The population estimate that was calculated in 2006 (Kemper et al. 2008) was 10,738 breeding adults which represented approximately $10 \%$ of the North American (and therefore the global) population. Using the most recent population estimates for individual lakes, the total estimate for the nine lakes with 100 or more birds is 8,946 breeding adults in 2009. Adding the lakes with fewer than 100 adults such as Lac Ste. Anne, and the many lakes with only a few adults, the population would likely approach 10,000 individuals.

Another factor underscoring the importance of ensuring that western grebe colonies are protected is that many of the colony sites are also used for breeding by other species. Some species such as the eared grebe (Podiceps nigricollis), Franklin's gull (Leucophaeus pipixcan), and common tern (Sterna hirundo) not only nest in the same colony site as the western grebes, but they also sometimes use the abandoned nests of western grebes as a base for building their own nests. Other birds that can be found in the colonies include black crowned night heron (Nycticorax nicticorax), white-faced ibis (Plegadis chihi), American coots (Fulica americana), red-necked grebe (Podiceps grisigena), redhead duck (Aythya americana), sora rail (Porzana carolina), yellow headed blackbird (Xanthocephalus xanthocephalus), black tern (Chlidonias niger), marsh wren (Cistothorus palustris), and Forster's tern (Sterna forsteri) (Hanneman and Heckbert 2001 and this study). 


\subsection{Habitat Requirements of Western Grebes in Alberta}

While a detailed analysis of habitat features was outside the scope of this study, some of the important elements that reflect on the potential impacts on grebe populations from anthropogenic or natural changes to habitat are mentioned here. In Alberta the characteristics of colony sites are:

1. A fish-bearing lake.

○ Because western grebes are fish-eating divers, they need a fish-bearing lake with open water where they can dive to pursue prey.

2. Vegetation characteristics suitable for nesting.

- The desired site features an extensive stand of bulrush or cattail vegetation. In Alberta, this is exclusively bulrush (Scirpus sp.), cattail (Typha sp.) or, to a minor extent, reeds (Phragmites sp.). Such vegetation provides shelter from waves, concealment from predators, building material for the nest and an anchor point for the nest.

- Usually nests are constructed within a bulrush stand where the previous season's growth still stands. When the ice on the lake begins melting in spring, the drifting ice pan may run aground on the lake bed where it removes any of the previous year's carryover old growth emergent vegetation it encounters. However, the ice stops in the shallow water, and may leave at least a fringe of emergent vegetation from the previous year. The benefit to the grebes of having the previous season's growth available is that they can begin nesting earlier than would be the case if they had to wait for new vegetation to grow tall enough to provide the required cover.

- There were a few situations where they nested in new growth. At the original colony site at Cold Lake, where the water depth at one of the colony sites was the deepest of any site recorded $(\sim 1.6 \mathrm{~m})$, all the old growth vegetation had been removed by ice action, and the birds had to wait for the new growth to emerge before nesting. At Lac Ste. Anne one season, it was noted that one group of grebes nested in the old bulrush and another group nested later that season in the new growth. The eggs of the first group hatched before the eggs of birds that nested in the new growth. A similar situation occurred at Wabamun Lake in 2009. There used to be a tremendous old growth reed bed at the current colony site, however, when TransAlta increased the water level, (completed in 2007), that reduced the density and extent of the reeds. Since then the grebes have nested closer to shore and some have even been nesting in the cattail. At Wabamun in 2009 , about half the birds nested in the cattail and half waited for the new growth to emerge. Again the birds nesting in new growth hatched eggs later.

3. A minimum depth of water.

- With falling water levels in 2009 at most lakes, two within-lake colony translocations were noted. At Hastings Lake the grebes abandoned one of the traditional colony sites because the water on the island had dropped, leaving the emergent vegetation out of the water. Nests were found at a new site at the other end of the lake. At Lake Isle this year, the same situation occurred with the water level dropping, exposing the emergent vegetation; this colony also relocated to a new site on the lake. 
- The vegetation is limited by the depth of water near the shoreline, for the plants have a narrow range of tolerance. The deepest water where nests were found was about 2 meters but most nests were in water $0.5 \mathrm{~m}$ to $1.5 \mathrm{~m}$.

4. A site sheltered from the prevailing winds.

- This year the Lake Isle colony, which had nested on the same small reef islands since at least 2001, relocated as described above. They nested in an area with old and new growth bulrushes and cattails and the birds may have had two nesting groups - one group nesting earlier in the old growth carry-over, and the second group delaying nesting until the new growth had developed. When a survey was initiated at the end of the nesting season the nests were gone. There had been a very strong wind event the previous weekend and from the direction the wind blew it was clear that the remnants of the colony had been destroyed in that storm event. This underscores why most locations on a typical lake are not suitable because the birds require a sheltered nesting area.

\subsection{Threats to Western Grebe Populations}

Grebes face many difficulties, some of them related to their colonial habit. If something dramatic happens to a single colony, a significant portion of the population could be killed or displaced. Ivey (2004) listed the problems facing grebes, based on the California situation. Those problems are considered in this section with some that are specific to Alberta.

\subsubsection{Direct Human-caused Mortality}

There have been reports of grebes that are killed in fences, hit by cars, killed by motorboat propellers, tangled in fishing line and striking towers (Riske 1976). It is suspected that commercial fishing nets can trap and drown grebes as well as other diving birds, like loons. Local fisheries biologists were questioned as to whether there have been western grebes in the nets of commercial fishermen and they confirmed that such deaths occur and some biologists have expressed alarm at the mortality numbers (D. Walty, pers. comm.). They felt that their test nets were not a problem. It appears there are certain times, such as the fall fishery (September and October), when the concern is not as great as the birds are scattered around the lake and migrating. However, setting nets during the spring fisheries that are near colonies of western grebes is particularly problematic and is not recommended. Summer fisheries on grebe lakes are also a cause for concern. This should be a consideration in issuing licences; in spring and summer, commercial or hobby net fishing should be discontinued on lakes that support populations of grebes.

\subsubsection{Mortality from Natural Causes}

As with all species, grebes face natural mortality. Riske (1976) documented western grebes freezing in ice in autumn and stated "this tendency has been known to result in sudden and sometimes considerable mortality of this species". Dead grebes have been found on nests that have apparently been killed by predators such as mink. Eggs are desired food items sought by crows (Corvus brachyrhynchos), ravens (Corvus corax), gulls and others. Newly hatched and young chicks are prey for an array of animals from northern pike (Esox lucius) to great blue herons (Ardea herodias). 
A concern exists where human activities enhance opportunities for natural predation. For example, during surveys at Cold Lake a few grebe nests still had incubating birds. As soon as the nests were approached by surveyors, the adult grebes would leave the nest, which allowed crows to come and prey upon the eggs. As a result of this, nest counts should be delayed until later in the season when most or all birds have completely finished nesting. At Wabamun Lake there is a large crow population that has actively preyed upon eggs. One could speculate that where grebes have more than one potential colony site at a lake, they can relocate around the lake allowing them to avoid egg predation. Where human activities have removed the nesting habitat, this limits alternative nesting sites.

\subsubsection{Water Level Changes}

Grebes can be negatively affected by three types of water level fluctuations - an increase in water levels, a decrease in water levels and water levels that fluctuate dramatically during nesting season. At Lesser Slave Lake a sudden increase in water levels in 2007 brought the level of the lake up to where the ice pack in spring was able to drift over the reef that supported the grebe colony and remove all the old-growth bulrush vegetation. The reed bed re-grew new shoots but this new growth did not provide enough cover for spring nesting so the colony was abandoned. If the water level retreats allowing the reef to develop old growth carry-over stands of bulrush there is no reason the colony would not be used again by grebes if land use changes have not dramatically impacted the habitat.

Blair Rippin, former Regional Wildlife Biologist in Northeast Region of Alberta (pers. comm.) performed surveys of waterbirds, including western grebes, in the Northeast Region in the late 1970 s and the 1980s. He said water levels have dropped sharply since then. Climate change has always been part of the Alberta landscape and western grebes have the ability to colonize new habitats if the traditional site has become unsuitable. If the current climate change is a drying cycle, the loss of lakes currently used by grebes will be detrimental as there are few other lakes that are suitable. Many of the 27 lakes that have at one time supported western grebes have suffered declines in water levels making them unsuited as western grebe habitat. If the current drying cycle reverses and water levels experienced in the1970s return, some of these lakes where grebes nested historically could once again be used if land use changes have not detrimentally impacted the habitat.

Reservoirs in southern Alberta sometimes have a few grebes but in general they are not suitable as the water level fluctuations do not allow for a stable development of emergent vegetation. If water levels fluctuate when the birds are on the nests, nests may become inundated or alternately, left high and dry.

Falling water levels, coupled with a high rate of eutrophication, contributes to winter kill of fish in lakes. As western grebes rely on fish for food, winterkill of fish would make the lake unsuitable for grebes even though there may be adequate emergent vegetation. Thunder Lake has suffered winterkill in recent years and this may explain why this onceoccupied lake no longer supports a western grebe population.

\subsubsection{Habitat Loss from Development}


Riske (1976) stated that Pigeon Lake, one of the largest lakes in the Parkland Region, saw cottage development triple from 1950 to 1966. With cottage building, most owners removed the emergent vegetation from in front of their lot, removed vegetation from the shoreline, leveled the shoreline, planted grass, and placed sand on the lake bed. While such practice is currently not legal without permission from Alberta Sustainable Resource Development, considerable habitat alteration due to cottage development and legal and illegal lakeshore development has occurred on most accessible fish-bearing lakes in Alberta.

\subsubsection{Grazing}

While livestock grazing adjacent to lakes can contribute to further degradation of shorelines, water quality and even direct destruction of nests, this has not been a widespread problem and where it occurs, strategic fencing can alleviate the problem.

\subsubsection{Recreation}

Salt and Wilk (1958) remarked, "Of all species of grebes the western grebe has suffered the most from the advance of civilization in Alberta: most of the large lakes formerly frequented by nesting colonies are now popular vacation resorts, and unlike the rednecked grebe, the western grebe appears to be unable to adjust itself to the disturbance of the reveller and his motor boat. Today nesting colonies are found only in quiet spots on the more remote lakes;"

Riske (1976) reported documented cases of grebe species abandoning nests and nest sites as a result of activities associated with recreation. He felt western grebes were the most susceptible of all Alberta grebes to water-based recreation - boating, fishing from boats, and water skiing. Grebes can be injured directly by strikes from propellers, and young can be separated from adults when very small. Nests can be swamped by boat wake and birds can be disturbed on the nests leading to predation or cooling of abandoned eggs.

At Lake Isle on the west island it was noted in the summer of 2003 that snowmobiles had driven over previous year's growth of bulrushes, flattening them. There was no nesting on that island the following summer.

\subsubsection{Oil Spills}

Western grebes at Wabamun Lake encountered an oil spill in 2005, where over 300 dead western grebes were recovered; there were undoubtedly more dead birds that were not found. Oil in the grebe colony reed bed lingered at least through the summer of 2009. Oil spills on the wintering grounds may affect Alberta birds but the connection between specific breeding grounds and wintering grounds has not been made.

\subsection{Population Trends of Western Grebes in Alberta}

\subsubsection{Northwest Boreal Region}


Hanneman and Heckbert (2001) surveyed the Northwest Boreal Region in 2000 and found large colonies at Utikuma and Lesser Slave lakes. Utikuma Lake has excellent waterbird habitat but winter kill of fish is problematic. They found three colonies on Utikuma but in the 2006 survey only a small colony with fewer than 100 western grebes was found. While logistics have prevented another search, Al Fontaine (pers. comm.) saw larger numbers of western grebes in the late summer of 2009 suggesting the colony had returned. Hanneman and Heckbert (2001) and historical information had noted large colonies of western grebes in various parts of the lake.

On Lesser Slave Lake, in 2006, a single large colony on a reef near the shoreline of the village of Joussard was found. In the spring of 2007, the water of Lesser Slave Lake rose about a meter which allowed the ice to scour the old growth reed habitat and the birds did not use the site from 2007 through 2009. Should the water in Lesser Slave Lake retreat to its original level it is expected that this site would once again be attractive to western grebes.

\subsubsection{Northeast Boreal Region}

The Northeast Boreal Region, characterized by its many lakes, has historically supported many western grebe colonies. The area has seen a steep decline in water levels since the 1970s when water levels were at their highest during the last 40 years. Of the 27 lakes in Alberta identified historically as having western grebe populations, 11 are in this zone; however, eight of the 11 no longer support a large colony. Colonies with 100 or more western grebes were found at Lac a Biche, Moose Lake, and Cold Lake, all large, deep lakes. In contrast, Hastings Lake, a small shallow lake near Edmonton, had over 100 nesting adults until this year when water levels dropped dramatically. At the former colony site the water level had dropped, leaving the bulrush vegetation on dry land. A new colony site was located but was in very shallow water and appeared to be just marginally suited for nesting. While 120 western grebes (adults and young) were counted on the lake, there were only 14 nests suggesting that there has been a serious decline resulting from decreasing water levels.

\subsubsection{Stony Plain (Central Boreal Region)}

Three lakes in the Stony Plain area have been surveyed annually since 2001 (Figure 2). Although there has been substantial year-to-year variation in western grebe numbers at those lakes, declining trends are evident. Lake Isle has demonstrated the least variation but it had the smallest colony, with 234 adults in 2007 being the largest number found, declining to 114 adults in 2008 and a similar number in 2009. In 2009 the grebes moved from their traditional site on two small reefs in the middle of the lake to a new site near the shore. At the original site water level on the reef had dropped, exposing the oldgrowth reeds; however, the new reeds, where the birds had nested in 2008, were still available.

Lac St. Anne underwent a significant decline, from a high of 1170 adults in 2001, until 2009 where there were fewer than 100 breeding adults. To confirm that the birds hadn't just moved to a different site, brood counts were performed for three years but the numbers of adults corresponded closely to the nest counts. There was no indicatinn of why the bird numbers declined. 
The population at Wabamun Lake was highest in 2003 with over 1500 adults, but declined to 600 adults in 2005. Surprisingly, after the oil spill, which occurred after the nesting season, the population increased on Wabamun Lake in 2006 with over 1000 adult grebes nesting in two colonies a few kilometres apart. Some of these birds must have translocated from another lake, as in 2005 at least 300 of the 600 birds in Wabamun Lake were killed by oil-related injuries but the 2006 count showed over 1000 adults. This population has continued to decline since then and in 2009 only 171 nests or 342 adults were counted.

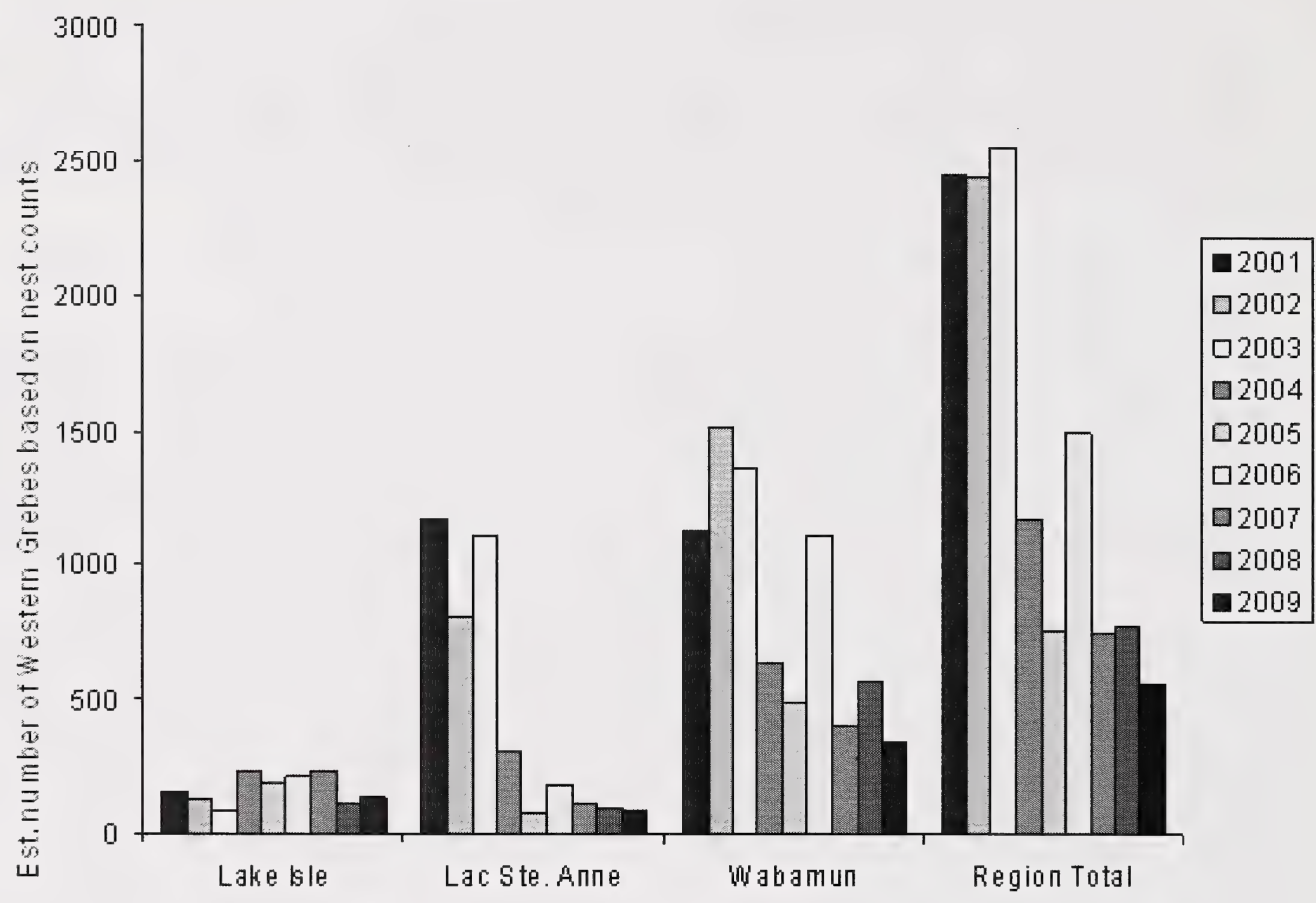

Figure 3. Estimated total number of adult western grebes (nests x 2) in the Stony Plain study area, 2001-2009.

\subsubsection{Central and Southern Alberta}

In southern, western and much of central Alberta, many lakes tend to be too shallow to sustain fish populations, lack suitable emergent vegetation, are subject to dramatic water level fluctuation (e.g., lakes used as irrigation reservoirs), or have substantial shoreline development and recreational activity. Pigeon Lake once had a thriving colony but the exponential expansion of cottage development and recreational activity is probably the cause of the loss of this colony. Only one western grebe was seen in the survey in 2008 . Gull Lake has supported a colony in the past. Again there is considerable recreational activity on the lake and while a colony has not been located, adult grebes were seen in the summer of 2009 so it will continue to be monitored for the presence of significant 
colonies in the future. In the Central Region only Buffalo Lake still has a large colony of western grebes.

While southern Alberta has many lakes that may be suitable, many are shallow such as Pakowki Lake (which means there may be an inadequate fish supply), or are part of a reservoir system where dramatic fluctuations in water levels preclude the establishment of suitable stable nesting habitat. Western grebes had been reported historically at Murray Lake and, in 2009, just over 100 breeding adults with young were found, but their nesting location remains unknown. Another colony was discovered with just over 100 breeding adults at Crow Indian Lake, where no colony had previously been reported. It was in suitable habitat - shallow water with good emergent vegetation. This site appears to be away from most boating activity. The colony is one that is used by many other species of waterbird. Other lakes in the area where western grebes have been reported, including those surveyed, all had fewer than 100 adults.

\subsection{Alberta's Western Grebes in a North American Context}

In Canada, western grebes are found only in the four western provinces, primarily on the prairies (Storer and Nuechterlein 1992). Alberta has about $10 \%$ of the total North American breeding population, indicating that populations here are a substantial portion of the North American breeding population. There are no data to show whether grebes from Alberta intermix on either the breeding or wintering grounds with populations in neighbouring provinces or states.

\subsection{CONCLUSIONS}

Alberta's Endangered Species Conservation Committee made a recommendation in 2006 to identify the western grebe as a Species of Special Concern. This status recommendation was based on the species initially qualifying for Threatened status, with a downgrade to Species of Special Concern because of the possibility of dispersal and exchange with adjacent populations. This study showed that there have been only 29 lakes in Alberta where western grebes have historically nested. Many of these lakes are no longer suitable for reasons of water depth or development. Currently, there are 10 lakes with populations of 100 or more breeding adults. Some of these lakes and colony sites are at risk because of the same factors that made other lakes unsuitable. It is likely that a change in the moisture regime to fill the lakes to levels of the 1970s could provide grebes the opportunity to return to historical lakes; however, this would only happen if the features that attract grebes are retained. In addition, current colony sites must be protected just to maintain the population. Even so, the numbers of birds in several of the colonies that have been surveyed since 2001 have declined. Opportunities to protect western grebe colonies through Protective Notations (PNTs) and seasonal sanctuaries are presently being pursued by FWD 


\subsection{LITERATURE CITED}

Alberta Sustainable Resource Development and Alberta Conservation Association. 2006. Status of the western grebe (Aechmophorus occidentalis) in Alberta. Alberta Sustainable Resource Development, Wildlife Status Report No. 60, Edmonton, Alberta. 29 pp.

Alberta Sustainable Resource Development. 2007. The 2005 General Status of Alberta Wild Species.

http://www.srd.alberta.ca/BioDiversityStewardship/SpeciesAtRisk/GeneralStatus/Default .aspx [Updated April 2010].

Berg, G., L. Wilkinson, H. Wollis, and D. Prescott. 2004. Aechmophorus occidentalis) Western and Eared (Podiceps nigricola) Grebes of Central and Parkland Alberta. 2004 Field summary. Alberta Sustainable Resource Development. Fish and Wildlife Division, Alberta species at Risk Report No. 94. Edmonton, Alberta.

Blood, D.A. and F. Backhouse. 1999. Wildlife at risk in British Columbia: western grebe. Ministry of Environment, Land and Parks, Victoria, British Columbia. 6 pp.

Burger, A.E. 1997. Status of the western grebe in British Columbia. BC Environment, Wildlife Branch. Wildlife Working Report WR-87. 40 pp.

Bower, J. 2003. Assessing southern Strait of Georgia marine bird population changes since 1980: what we know and what we need to know. 2003 Georgia Basin/Puget Sound Research Conference, Western Washington University. 7 pp.

Eichhorst, B.A. 1992. An analysis of western grebe banding and recovery data. North American Bird Bander 17(3):108-115.

Elbert, R.A. and D.W. Anderson. 1998. Mercury levels, reproduction, and haematologyin western grebes from three California lakes, USA. Environmental Toxicology and Chemistry 17(2):210-213.

Environment Canada. 2002. Avian life history database: western grebe life history information. http://www.on.ec.gc.ca/wildlife/wildspace/life.cfm [Accessed 9 October 2008]

Fisher, C. and J. Acorn. 1998. Birds of Alberta. Lone Pine Publishing, Edmonton, Alberta. 384 pp.

Found C. and A. Hubbs. 2004. Survey of colonial nesting birds and lakeshore habitats in Northeast Alberta. Alberta Sustainable Resource Development, Fish and Wildlife Division, Alberta Species at Risk Report No. 88, Edmonton, Alberta. 32 pp.

Found, C., S. M. Webb, and M. S. Boyce. 2008. Selection of lake habitat by waterbirds in the boreal transition zone of northeast Alberta. Can. J. Zool. 86: 277-285. 
Hanneman, M. and M. Heckbert. 2001. Colonial Nesting Waterbird Survey in the Northwest Boreal Region - 2000. Alberta Sustainable Resource Development, Fisheries and Wildlife Management Division, Alberta Species at Risk Report No. 7, Edmonton, Alberta

Hanus, S. 2002. Western (Aechmorphorus occidentalis) and eared (Podiceps nigricola) grebe data of Alberta. Alberta Sustainable Resource Development, Fish and Wildlife Division, Edmonton, Alberta. 112 pp.

Hanus, S. 2002b. Western Grebe and eared grebe data synthesis. Unpublished. Alberta Sustainable Resource Development, Fish and Wildlife Division. Spruce Grove, Alberta.

Hanus, S., H. Wollis, and L. Wilkinson. 2002. Western (Aechmophorus occidentalis) and eared (Podiceps nigricollis) grebes of central Alberta: inventory, survey techniques, and management concerns. Alberta Sustainable Resource Development, Fish and Wildlife Division, Species at Risk Report No. 41. Edmonton, Alberta. 45 pp.

Hanus, S., H. Wollis, and L. Wilkinson. 2002. Western (Aechmophorus occidentalis) and eared (Podiceps nigricollis) grebes of central Alberta.: 2002 Field Summary. Alberta Sustainable Resource Development, Alberta Fish and Wildlife Division, Alberta Species at Risk Report No 60. Edmonton, Alberta.

Hanus, S., L. Wilkinson and H. Wollis. 2003. Western (Aechmophorus occidentalis) Grebes of Central Alberta: 2003 Field Summary Alberta Sustainable Resource Development, Fish and Wildlife Division, File report.

Ivey, G. L. 2004. Conservation assessment and Management Plan for Breeding Western and Clarke's Grebes in California. 89 pp.

Kemper, C., H. Wollis, C. Found, D. Prescott, and M. Heckbert. 2008. Western Grebes (Aechmophorus occidentalis) in Alberta: 2006 Field Summary. Alberta Sustainable Resource Development, Fish and Wildlife Division Alberta species at Risk Report No. 121. Edmonton Alberta. $17 \mathrm{pp}$

Purdy, R. O., D. C. Parkin and J.D. Folinsbee. 1983. Wildlife Surveys of Selected Edmonton Area Lakes. Unpub. Rept. Fish and Wildlife Division, Alberta Energy and Natural Resources $135 \mathrm{pp}$.

Riske, M. E. (1976) Environmental and Human Impacts upon Grebes Breeding in Central Alberta. PhD. Thesis. University of Calgary. Calgary, Alberta. 482 pp.

Salt, W. R. and A. L. Wilk. 1958. The Birds of Alberta. Government of Alberta, Edmonton, Alberta. 511 pp.

Semenchuk, G.P. 1992. The Atlas of Breeding Birds of Alberta. Federation of Alberta Naturalists, Edmonton, Alberta. 391 pp. 
Storer, R. W. and G. L. Nuechterlein. 1992. Western and Clark's Grebe. In The Birds of North America, No. 26 (A. Poole, P. Stettenheim, and F. Gill, Eds.). Philadelphia: The Academy of Natural Sciences; Washington, DC: The American Ornithologists' Union.

Strong, W.L. and K.R. Leggat. 1981. Ecoregions of Alberta. Technical Report T/4, Alberta Energy and Natural Resources, Edmonton, Alberta AB. 64 pp. 
Appendix 1. Lakes historically occupied by $100+$ adult western grebes.

\begin{tabular}{|c|c|c|c|c|c|}
\hline LAKE & $\begin{array}{c}\text { LOCATION } \\
\text { (Natural } \\
\text { Region) }\end{array}$ & $\begin{array}{l}\text { \#Adults } \\
\text { Most } \\
\text { Recent } \\
\text { Estimate }\end{array}$ & YEAR & $\begin{array}{c}\text { \# Adults } \\
\text { Highest } \\
\text { Estimate }\end{array}$ & YEAR \\
\hline Angling & NE Boreal & 1 & 2008 & 1680 & 1981 \\
\hline Beaverhill & Parkland & No nesting & 2009 & 600 & 1960 \\
\hline Buffalo & Parkland & 888 & 2008 & 1030 & 2006 \\
\hline Cold & NE Boreal & 582 & 2008 & 2000 & 1979 \\
\hline Conn & NE Boreal & No nesting & 2009 & 300 & 1993 \\
\hline $\begin{array}{l}\text { Crow } \\
\text { Indian }\end{array}$ & Prairies & 100 & 2009 & 100 & 2009 \\
\hline Frog & NE Boreal & 0 & 2008 & 600 & 1991 \\
\hline Garner & NE Boreal & 0 & 2008 & 102 & 1995 \\
\hline Gull & Parkland & $\begin{array}{c}\text { Nesting } \\
\text { questioned }\end{array}$ & 2009 & 170 & 2009 \\
\hline Hastings & Parkland & 120 & 2009 & 440 & 2006 \\
\hline Isle & $\begin{array}{l}\text { Central } \\
\text { Boreal } \\
\end{array}$ & 130 & 2009 & 154 & 2007 \\
\hline $\begin{array}{c}\text { Lac La } \\
\text { Biche }\end{array}$ & NE Boreal & 3226 & 2007 & 3227 & 2007 \\
\hline $\begin{array}{c}\text { Lac Ste } \\
\text { Anne }\end{array}$ & $\begin{array}{l}\text { Central } \\
\text { Boreal } \\
\end{array}$ & 84 & 2009 & 1500 & 1984 \\
\hline $\begin{array}{l}\text { Lesser } \\
\text { Slave }\end{array}$ & NW Boreal & 0 & 2009 & 3742 & 2002 \\
\hline Marguerite & NE Boreal & $\begin{array}{c}\text { No recent } \\
\text { nesting }\end{array}$ & & 120 & 1982 \\
\hline Moose & NE Boreal & 353 & 2008 & 400 & 1990 \\
\hline Muriel & NE Boreal & $\begin{array}{c}\text { No recent } \\
\text { nesting }\end{array}$ & & 386 & 1990 \\
\hline Murray & Prairie & 107 & 2009 & 107 & 2009 \\
\hline North Buck & $\begin{array}{l}\text { Central } \\
\text { Boreal }\end{array}$ & 0 & 2007 & 124 & 1991 \\
\hline Pigeon & Parkland & 1 & 2008 & $100 *$ & 1971 \\
\hline Reita & NE Boreal & 0 & 2008 & 266 & 1980 \\
\hline Sandy & Parkland & 0 & 2003 & 150 & 2002 \\
\hline Sante & NE Boreal & $\begin{array}{c}\text { No recent } \\
\text { nesting }\end{array}$ & $=$ & 150 & 1993 \\
\hline Saskatoon & NW Boreal & $\begin{array}{c}\text { No recent } \\
\text { nesting }\end{array}$ & & 500 & $1992^{* *}$ \\
\hline Thunder & $\begin{array}{l}\text { Central } \\
\text { Boreal }\end{array}$ & 0 & 2008 & $273^{*}$ & 1981 \\
\hline Utikuma & NW Boreal & 1220 & 2009 & $2200 ?$ & 2000 \\
\hline Wabamun & $\begin{array}{l}\text { Central } \\
\text { Boreal }\end{array}$ & 340 & 2009 & 1510 & 2002 \\
\hline
\end{tabular}

* Count done after fledging would include young of year.

** Birds seen in September and may have been migrating. 





\section{RECYCLED \\ $\sqrt{2}$ Paper made from FSC recycled material $\underset{\text { www.tsc.org }}{\text { FSC }}$ FSC $^{\circledR} 004283$}

